\title{
GAMBARAN ANTARA PERSEPSI PERUBAHAN FISIK DENGAN KECEMASAN IBU MENOPAUSE DI DESA DERMASANDI KECAMATAN PANGKAH KABUPATEN TEGAL
}

\author{
Galuh Tunjung Sari ${ }^{1}$, Rahardjo Apriatmoko², Luvi Dian ${ }^{3}$ \\ Email :galuh.tunjungz@gmail.com \\ ${ }^{1}$ Politeknik Harapan Bersama, Jalan Mataram No 9 Kota Tegal 52142, Indonesia. \\ Telp (0283) 352000 \\ ${ }^{2,3}$ Sekolah Tinggi Ilmu Kesehatan Ngudi Waluyo Ungaran, Indonesia
}

\begin{abstract}
Abstrak
Persepsi bahwa menopause adalah suatu ancaman hanya berdasar pada tradisi. Timbulnya perasaan tidak berharga, tidak berarti, dan semacamnya memunculkan kekhawatiran tersendiri. Dengan demikian kecemasan menghadapi menopause adalah perasaan gelisah dan khawatir dari adanya perubahan fisik, sosial, maupun seksual. Tujuan penelitian ini adalah untuk mengetahui gambaran antara persepsi perubahan fisik dengan kecemasan ibu menopause di Desa Dermasandi Kecamatan Pangkah Kabupaten Tegal tahun 2013. Metode penelitian yang digunakan dalam penelitian ini adalah deskriptif korelasional. Pengambilan sampel berjumlah 76 orang dengan kriteria inklusi dan eksklusi dengan tehnik purposive sampling. Pengumpulan data dengan data primer (wawancara dan kuesioner).

Hasil penelitian menunjukkan sebagian besar responden memiliki persepsi perubahan fisik ibu menopause adalah positif atau wajar $(53,2 \%)$ dengan tingkat kecemasan sedang (46,8\%). Terdapat gambaran yang bermakna antara persepsi perubahan fisik dengan kecemasan ibu menopause di Desa Dermasandi Kecamatan Pangkah Kabupaten Tegal tahun 2013. Analisis penelitian ini menggunakan analisis deskriptif. Melihat fenomena diatas maka bidan perlu memberikan pendidikan kesehatan kepada ibu menopause tentang perubahan fisik menopause serta memberikan saran kepada ibu menopause untuk banyak mengkonsumsi makanan yang mengandung fitoestrogen, mengurangi makanan berlemak serta selalu berolahraga.
\end{abstract}

Kata Kunci : Persepsi, Menopause, Kecemasan

\section{Pendahuluan}

Dalam perjalanan hidupnya seorang wanita yang mencapai umur sekitar 45 tahun mengalami penuaan indung telur, sehingga tidak sanggup memenuhi hormon estrogen. Sistem hormonal seluruh tubuh mengalami kemunduran dalam mengeluarkan hormonnya. Perubahan pengeluaran hormon menyebabkan berbagai perubahan fisik dan psikis. ${ }^{[1]}$

Perubahan fisik dan psikis tersebut paling banyak terjadi pada wanita karena pada proses menua terjadi suatu fase yaitu fase menopause. Fase menopause dikenal sebagai berhentinya menstruasi, yang disebabkan oleh hilangnya aktivitas folikel ovarium. ${ }^{[2]}$

Menopause merupakan suatu proses peralihan dari masa produktif menuju perlahan-lahan ke masa non-produktif yang disebabkan berkurangnya hormon estrogen dan progesteron. Dengan terjadinya menopause pada wanita, biasanya diikuti dengan berbagai gejolak meliputi aspek fisik maupun psikologis yang juga dapat mempengaruhi berbagai aspek kehidupan wanita tersebut. ${ }^{[3]}$

Istilah menopause adalah suatu kondisi fisiologis pada wanita yang telah memasuki proses penuaan (aging). Seringkali wanita menghadapi menopause dengan rasa cemas dan was-was karena menopause identik dengan ketuaan. Gejala premenopause akibat menurunnya kadar estrogen sering menimbulkan gejala yang sangat menganggu aktivitas kehidupan para wanita, bahkan mengancam kebahagiaan rumah tangga. Masalah yang muncul, termasuk hilangnya kesuburan dan meningkatnya risiko osteoporosis pada kondisi menjelang menopause. ${ }^{[2]}$ 
Persepsi bahwa menopause adalah suatu ancaman hanya berdasar pada tradisi. Pada beberapa masyarakat, wanita menyambut dengan gembira karena mereka tidak lagi mengandung dan mempunyai kebebasan lebih besar. Di negara barat, yang lebih menekankan pada kemudaan, menopause sering dirasakan sebagai sesuatu yang negatif. Hubungan dengan pasangan dan anak-anak mungkin terganggu, wanita tersebut menjadi cemas tentang masa depannya, atau mungkin merasa menjadi kurang menarik lagi. ${ }^{[4]}$

Dalam menyikapi dirinya yang akan memasuki masa menopause, beberapa wanita menyambutnya dengan biasa. Mereka menganggap kondisi ini bagian dari siklus hidupnya. Namun banyak wanita yang mengeluh bahwa dengan datangnya premenopause mereka akan menjadi pencemas. Kecemasan yang muncul pada wanita menopause sering dihubungkan dengan adanya kekhawatiran dalam menghadapi suatu situasi yang sebelumnya tidak pernah dikhawatirkan. Wanita seperti ini sangat sensitif terhadap pengaruh emosional akibat fluktuasi hormon. ${ }^{[5]}$

Dari studi pendahuluan yang telah dilakukan di Desa Dermasandi Kecamatan Pangkah Kabupaten Tegal didapatkan jumlah penduduk pada bulan Oktober tahun 2010 sebanyak 5320 orang sedangkan jumlah ibu menopause sebanyak 103 orang. Berdasarkan pengamatan menunjukkan bahwa menopause menimbulkan perubahan baik fisik maupun psikis. Berdasarkan fenomena di atas penulis tertarik untuk melakukan penelitian tentang "Hubungan antara Persepsi Perubahan Fisik dengan Kecemasan Ibu Menopause di Desa Dermasandi Kecamatan Pangkah Kabupaten Tegal"'.

\section{Metode Penelitian}

Penelitian ini merupakan desain penelitian deskriptif korelasional yaitu mendeskripsikan variabel bebas dan terikat, kemudian melakukan korelasi antara kedua variabel yaitu variabel bebas dan variabel terikat, sehingga dapat diketahui adanya hubungan variabel bebas terhadap variabel terikat. Pendekatan yang digunakan dalam penelitian ini adalah cross sectional yaitu pengukuran variabel bebas dan variabel terikat hanya satu kali pada satu saat. ${ }^{[6]}$

Populasi dalam penelitian ini adalah seluruh ibu menopause di Desa Dermasandi Kecamatan Pangkah Kabupaten Tegal sebanyak 103 orang yang tercatat pada bulan Januari tahun 2013. Dalam penelitian ini peneliti menggunakan teknik pengambilan sampel dengan cara purposive sampling, yaitu didasarkan pada suatu pertimbangan tertentu yang dibuat oleh peneliti sendiri, berdasarkan ciri atau sifatsifat populasi yang sudah diketahui sebelumnya. ${ }^{[7]}$

Pengambilan sampel menggunakan kriteria inklusi dalam penelitian ini adalah : bersedia menjadi responden, mampu membaca dan menulis, dapat berkomunikasi dengan baik, lama menopause (berhenti mens $\geq 12$ bulan) dan tidak $\geq 7$ tahun dan masih bersuami atau memperoleh ijin dari suami. Kriteria eksklusi dalam penelitian ini adalah: menolak menjadi responden, tidak dapat membaca dan menulis, ibu tidak dapat berkomunikasi dengan baik, lama menopause (berhenti mens $\leq 12$ bulan) dan $>7$ tahun dan suami telah tiada atau suami tidak mengijinkan.

Yang menjadi sampel dalam penelitian ini berjumlah adalah ibu menopause yang ada di Desa Dermasandi Kecamatan Pangkah Kabupaten Tegal yang tercatat pada bulan Januari 2013 yaitu 76 orang. Mengingat jumlah populasi lebih dari 100 orang. ${ }^{[8]}$

Pengumpulan data yang digunakan oleh peneliti dengan membagikan kuesioner dan wawancara langsung yang kemudian data dianalisis menggunakan analisis deskriptif.

\section{Hasil dan Pembahasan}

Penelitian dilakukan pada 76 responden yaitu ibu menopause di Desa Dermasandi Kecamatan pangkah Kabupaten Tegal. Dari hasil analisis data diperoleh ibu dengan sebagian besar responden memiliki persepsi perubahan fisik ibu menopause positif (wajar) yaitu sebanyak 41 orang $(53,9 \%)$ sedangkan sebagian kecil responden mempunyai persepsi perubahan fisik ibu menopause negatif (tidak wajar) tentang menopause yaitu sebanyak 35 orang 
(46,1\%). Hal ini menunjukkan persepsi ibu tentang menopause adalah positif, mereka merasa wajar akan perubahan fisik yang terjadi pada mereka.

Tabel 1. Distribusi persepsi perubahan fisik ibu menopause di Desa Dermasandi Kecamatan Pangkah Kabupaten Tegal.

\begin{tabular}{ccc}
\hline $\begin{array}{c}\text { Persepsi } \\
\text { perubahan fisik }\end{array}$ & $\begin{array}{c}\text { Jumlah } \\
\text { (orang) } \\
\text { (f) }\end{array}$ & $\begin{array}{c}\text { Prosentase } \\
(\%)\end{array}$ \\
\hline Negatif & 35 & 46,1 \\
Positif & 41 & 53,9 \\
\hline Total & 76 & 100,0 \\
\hline
\end{tabular}

Jika dilihat dari hasil wawancara variabel independen yaitu persepsi perubahan fisik ibu menopause sebagian besar responden memiliki persepsi positif (+) pada perubahan fisik ibu menopause yaitu perubahan kulit dari berubahnya tekstur kulit, kerutan kulit yang terkadang disertai dengan jerawat sebanyak 39 orang $(51,3 \%)$. Sebagian kecil responden memiliki persepsi negatif (-) pada perubahan fisik ibu menopause yaitu ketidakteraturan siklus haid sebanyak 30 responden $(39,5 \%)$.

Dari data di atas dapat dilihat bahwa sebagian besar responden memiliki persepsi perubahan fisik ibu menopause positif (wajar). Penyebabnya karena sebagian besar responden merasa mereka akan mengalami masa menopause dengan bertambahnya usia mereka. Mereka menganggap hal ini tidak mungkin bisa dihindari.

Persepsi adalah pengalaman tentang objek, peristiwa, atau hubungan-hubungan yang diperoleh dengan menyimpulkan informasi dan menafsirkannya. Persepsi juga memiliki arti memberikan makna kepada stimulus. ${ }^{[9]}$

Berkaitan dengan faktor-faktor yang berperan dalam persepsi dapat dikemukakan beberapa faktor, yaitu : objek yang dipersepsi, alat indera, syaraf dan pusat susunan syaraf, serta perhatian. ${ }^{[10]}$

Dalam penelitian ini peneliti mengukur persepsi perubahan fisik ibu menopause dengan menggunakan metode self report. Self report merupakan suatu metode dimana jawaban yang diberikan dapat menjadi indikator sikap seseorang. Namun kelemahannya adalah bila individu tidak menjawab pertanyaan yang diajukan maka tidak dapat mengetahui pendapat atau sikapnya. ${ }^{[11]}$

Skala sikap disusun untuk mengungkap sikap pro dan kontra, positif dan negatif, setuju dan tidak setuju terhadap suatu obyek sosial. Pernyataan sikap terdiri dari dua macam yaitu pernyataan favorable (mendukung atau memihak) dan unfavorable (tidak mendukung/tidak memihak) pada obyek sikap. ${ }^{[1]}$

Jika merujuk pada pernyataan diatas, bahwa mengukur persepsi hampir sama dengan mengukur sikap, maka skala sikap yang disusun untuk mengungkap sikap dapat dipakai atau dimodifikasi untuk mengungkap persepsi sehingga dapat diketahui apakah persepsi seseorang positif atau negatif terhadap suatu hal atau obyek. [11]

Hasil penelitian persepsi perubahan fisik ibu menopause di Desa Dermasandi Kecamatan Pangkah Kabupaten Tegal ini diperoleh dengan cara wawancara terhadap responden. Dari hasil wawancara tersebut diperoleh hasil persepsi perubahan fisik ibu menopause.

Persepsi bahwa menopause adalah suatu ancaman hanya berdasar pada tradisi. Pada beberapa masyarakat, wanita menyambut dengan gembira karena mereka tidak lagi mengandung dan mempunyai kebebasan lebih besar. Di negara barat, yang lebih menekankan pada kemudaan, menopause sering dirasakan sebagai sesuatu yang negatif. Hubungan dengan pasangan dan anak-anak mungkin terganggu, wanita tersebut menjadi cemas tentang masa depannya, atau mungkin merasa menjadi kurang menarik lagi. ${ }^{[4]}$

Tugas bidan dalam hal ini adalah memberikan penyuluhan atau konseling pada responden tentang perubahan fisik ibu menopause beserta memberikan penjelasan mengenai penyebabnya. 
Tabel 2. Distribusi kecemasan ibu menopause di Desa Dermasandi Kecamatan Pangkah Kabupaten Tegal.

\begin{tabular}{ccc}
\hline Kecemasan & $\begin{array}{c}\text { Jumlah } \\
\text { (orang) } \\
\text { (f) }\end{array}$ & $\begin{array}{c}\text { Prosentase } \\
(\%)\end{array}$ \\
\hline CemasRingan & 46 & 60,5 \\
CemasSedang & 30 & 39,5 \\
Cemas Berat & 0 & 0 \\
\hline Total & 76 & 100,0 \\
\hline
\end{tabular}

Hasil penelitian menunjukan bahwa sebagian besar responden yang memiliki tingkat kecemasan ringan yaitu sebanyak 46 responden $(60,5 \%)$, responden yang memiliki tingkat kecemasan sedang yaitu sebanyak 30 responden $(39,5 \%)$ sedangkan responden yang mengalami tingkat kecemasan berat tidak ada sama sekali $(0 \%)$.

Dari data di atas dapat dilihat bahwa sebagian responden memiliki tingkat kecemasan sedang. Dimana responden yang memiliki tingkat kecemasan sedang memungkinkan memusatkan pada hal lain dan mengesampingkan hal yang lain sehingga seolah-olah mengabaikan datangnya menopause walaupun menolak keras akan datangnya menopause dengan timbulnya keluhan seperti rasa cemas, tertekan dan mudah tersinggung.

Jika dilihat dari karakteristik responden yaitu pendidikan responden sebagian besar responden memiliki latar belakang pendidikan SD (50\%). Tingkat pendidikan dan status ekonomi yang rendah pada seseorang akan memudahkan orang tersebut mengalami kecemasan. ${ }^{[12]}$

Jika dilihat dari tempat penelitian yaitu Desa Dermasandi Kecamatan Pangkah Kabupaten Tegal berupa pedesaan di dataran rendah, dengan mayoritas penduduknya yang memiliki latar belakang pendidikan SD dan bekerja sebagai ibu rumah tangga serta berfikiran esensial, yaitu lebih mendahulukan kebutuhan primer daripada kebutuhan lain. Hal-hal tersebut tidak berpengaruh dalam masa menopause sehingga seolah-olah mengesampingkan masa menopause yang diikuti perubahan fisik yang tengah terjadi pada mereka.
Ada 2 faktor presipitasi yang mempengaruhi kecemasan yaitu : faktor internal (pengetahuan, keadaan fisik, lingkungan dan situasi, pendidikan dan status ekonomi, tipe kepribadian, umur, jenis kelamin, dan sosial budaya) dan faktor eksternal yaitu ancaman integritas dan konsep diri. ${ }^{[12]}$

Perubahan yang terjadi selama menopause adalah : perubahan organ reproduksi, perubahan hormon, perubahan fisik serta perubahan emosi. ${ }^{[13]}$

Berikut faktor-faktor yang mempengaruhi terjadinya menopause, antara lain : faktor psikis, faktor budaya ekonomi lingkungan, serta adanya faktor lain. ${ }^{[2]}$

Kecemasan (ansietas/ anxiety) adalah gangguan alam perasaan (affective) yang ditandai dengan perasan ketakutan atau kekhawatiran yang mendalam dan berkelanjutan, tidak mengalami gangguan dalam menilai realitas (Reality Testing Ability/RTA), kepribadian masih utuh (tidak mengalami keretakan kepribadian/ splitting of personality), perilaku dapat terganggu tetap masih dalam batas normal. Kecemasan dimaknai juga sebagai reaksi normal dari keadaan yang sangat menekan serta merupakan hasil interaksi dari proses psikologi dan proses fisiologi dalam tubuh manusia. Kecemasan menunjukkan adanya kewaspadaan dalam bentuk reaksi terhadap bahaya atau terhadap suatu keadaan yang memungkinkan individu tersebut akan kehilangan kendali. Dalam keadaan normal, kecemasan biasanya tidak berlangsung lama, namum dapat berpengaruh buruk terhadap individu jika seringkali terjadi. ${ }^{[14]}$

Kecemasan yang ibu menopause hadapi adalah karena takut kehilangan peran sebagai wanita, takut kesepian dan tidak ada teman yang mau diajak bicara atau diminta nasehat. ${ }^{[15]}$

Respon individu terhadap ansietas beragam, cemas diklasifikasikan menjadi beberapa tingkat, yaitu: cemas ringan, cemas sedang, cemas berat dan panik. ${ }^{[12]}$

Perubahan fisik yang terjadi sejalan dengan masa menopause sudah tentu menimbulkan kesan yang mendalam bagi kehidupan kaum hawa. Timbulnya perasaan tidak berharga dan tidak berarti serta 
kekhawatiran akan adanya kemungkinan bahwa orang-orang yang dicintainya akan berpaling dan meninggalkannya. Dengan demikian, kecemasan menghadapi menopause adalah perasaan gelisah dan khawatir dari adanya perubahan fisik, sosial maupun seksual. ${ }^{[5]}$

Hasil penelitian tingkat kecemasan ibu menopause di Desa Dermasandi Kecamatan Pangkah Kabupaten Tegal ini diperoleh dengan cara pengisian kuesioner terhadap responden. Dari kuesioner tersebut diperoleh tingkat kecemasan ibu menopause. Kuesioner kecemasan ibu menopause menggunakan Hamilton Rating Scale for Anciety (HRS-A).

Tugas bidan dalam hal ini adalah memberikan penyuluhan atau konseling pada responden mengenai bagaimana cara mengurangi keluhan yang dialami sehingga dapat mengurangi kecemasan ibu menopause sehubungan dengan perubahan fisik yang terjadi.

\section{Kesimpulan}

Pada penelitian yang dilakukan di Desa Dermasandi Kecamatan Pangkah Kabupaten Tegal tentang persepsi perubahan fisik dengan kecemasan ibu menopause didapatkan hasil :

a. Persepsi ibu tentang perubahan fisik ibu menopause sebagian besar memiliki persepsi positif $(53,2 \%)$ sebanyak 41 responden.

b. Kecemasan ibu dalam menghadapi menopause sebagian besar adalah kecemasan sedang $(46,8 \%)$ yaitu sebanyak 36 responden.

Keluarga memiliki peranan penting dalam memberi dukungan pada ibu menopause, perlunya pengertian dan pemahaman tentang perubahan ibu menopause dari masyarakat khususnya keluarga sehingga ibu dapat menjalani masa menopause dengan tenang.

Sebaiknya ibu menopause banyak mengkonsumsi makanan yang mengandung fitoestrogen seperti kedelai, polong, sereal, kacang-kacangan, tauge serta produk olahannya dan mengurangi makanan berlemak serta selalu berolahraga sehingga ibu dapat menjalani masa menopause dengan tenang serta kecemasan dan keluhan yang dirasakan dapat berkurang.

\section{Daftar Pustaka}

[1] Manuaba, I. G. B. Memahami Kesehatan Reproduksi Wanita. Jakarta : Arcan. 2002.

[2] Proverawati, Atikah. Menopause dan Sindrome Premenopause. Yogyakarta : Nuha Medika. 2010.

[3] Lestary, Dwi. Seluk Beluk Menopause. Jogjakarta : Garai Ilmu. 2010

[4] Jones. Setiap Wanita. Jakarta : Della Pratasa Publishing. 2001

[5] Smart, Aqila. Bahagia di Usia Menopause. Jogjakarta : A+ Books. 2010.

[6] Notoadmodjo, S. Metodologi Penelitian Kesehatan. Jakarta : Rineka Cipta. 2002.

[7] Notoadmodjo, S. Pendidikan dan Perilaku Kesehatan. Jakarta : Rineka Cipta. 2005.

[8] Arikunto, S. Prosedur Penelitian Suatu Pendekatan Praktek. Jakarta : Rineka Cipta. 2002.

[9] Notoadmodjo, S. Ilmu Perilaku Kesehatan. Jakarta : Rineka Cipta. 2010

[10] Walgito, Bimo. Pengantar Psikologi Umum. Yogyakarta : Andi. 2003

[11] Azwar, Saifudin. Sikap Manusia Teori Skala dan Pengukurannya. Pustaka Pelajar : Jakarta. 2003

[12] Asmadi. Tehnik Prosedural Keperawatan ; Konsep dan Aplikasi Kebutuhan Dasar Klien. Jakarta : Salemba Medika. 2008

[13] Joseph, H.K. dan Nugroho, M. Catatan Kuliah Obstetri dan Ginekologi. Yogyakarta : Ar-Ruz Media. 2010

[14] Hawari, Dadang. Manajemen Stress, Cemas, dan Depresi. Jakarta : Gaya Baru. FKUI. 2008.

[15] Mansjoer, A dkk. Kapita Selekta Kedokteran Jilid I. Jakarta : Media Aesculapius. FKUI. 2005. 